\title{
Monacyclinones, New Angucyclinone Metabolites Isolated from Streptomyces sp. M7_15 Associated with the Puerto Rican Sponge Scopalina ruetzleri
}

\author{
Jan Vicente ${ }^{1,2}$, Allison K. Stewart ${ }^{1}$, Ryan M. van Wagoner ${ }^{1}$, Elizabeth Elliott ${ }^{1}$, \\ Andrea J. Bourdelais ${ }^{1}$ and Jeffrey L. C. Wright ${ }^{1, *}$ \\ 1 Center for Marine Science, University of North Carolina Wilmington, 5600 Marvin K. Moss Lane \\ Wilmington, NC 28409, USA; E-Mails: jvicente@umces.edu (J.V.); stewarta@uncw.edu (A.K.S.); \\ r.m.vanwagoner@pham.utah.edu (R.M.W.); elliotte@uncw.edu (E.E.); \\ bourdelaisa@uncw.edu (A.J.B.) \\ 2 Institute of Marine and Environmental Technology, Center for Environmental Science, \\ University of Maryland, 701 E Pratt St Suite 236, Baltimore, MD 21202, USA \\ * Author to whom correspondence should be addressed; E-Mail: wrightj@uncw.edu; \\ Tel.: +1-910-962-2397; Fax: +1-910-962-2410.
}

Academic Editor: Valeria Costantino

Received: 24 April 2015 / Accepted: 2 July 2015 / Published: 29 July 2015

\begin{abstract}
During an investigation of new actinomycete species from Caribbean sponges for novel bioactive natural products, frigocyclinone (1), dimethyldehydrorabelomycin (3) and six new angucyclinone derivatives were isolated from Streptomyces sp. strain M7_15 associated with the sponge Scopalina ruetzleri. Of these, monacyclinones A-B (4-5) contain the core ring structure of dehydrorabelomycin (2) with the aminodeoxysugar found in frigocyclinone (1). Monacyclinone C (6) is a hydroxylated variant of frigocyclinone (1) and monacyclinone D (7) is a Baeyer Villiger derivative of (6) which also exists as the open chain hydrolysis product monacyclinone E (8). Monacyclinone F (9) contains two unique epoxide rings attached to the angucyclinone moiety and an additional aminodeoxysugar attached through an angular oxygen bond. All structures were confirmed through spectral analyses. Activity against rhabdomycosarcoma cancer cells (SJCRH30) after $48 \mathrm{~h}$ of treatment was observed with frigocyclinone $\left(1 ; \mathrm{EC}_{50}=5.2 \mu \mathrm{M}\right)$, monacyclinone $\mathrm{C}(6 ; 160 \mu \mathrm{M})$, monacyclinone $\mathrm{E}$ $(8 ; 270 \mu \mathrm{M})$, and monacyclinone $\mathrm{F}(\mathbf{9} ; 0.73 \mu \mathrm{M})$. The strongest bioactivity against rhabdomycosarcoma cancer cells and gram-positive bacteria was exhibited by compound $\mathbf{9}$, suggesting that the extra aminodeoxysugar subunit is important for biological activity.
\end{abstract}


Keywords: angucyclinone; Streptomyces; antibiotic; anticancer

\section{Introduction}

Marine sponges harbor a highly complex diversity of microorganisms including a variety of the pharmaceutically valuable Streptomyces sp. [1-5]. Sponge-associated Streptomyces sp. are dominant producers of aromatic polyketides such as anthracyclines, tetracyclines and angucyclinones that contain a benzene-anthraquinone moiety [6,7]. Over 100 angucyclinone derivatives have been discovered thus far as a result of a variety of oxygenation, glycosylation, and dehydration reactions [8-11]. These derivatives have all shown a wide range of biological activities (i.e., anti-tumor, antifungal, antiviral, antimicrobial) [12-14].

Due to the promising diversity of sponge associated Streptomyces sp. and their ability to produce secondary metabolites, sponges in the Caribbean were screened for the presence of Streptomyces sp. A unique isolate (Streptomyces sp. M7_15) was cultivated from the Puerto Rican sponge Scopalina ruetzleri [15] collected from Mona Island [16]. The main compound produced by Streptomyces sp. M7_15 was found to be the angucyclinone derivative frigocyclinone which was previously isolated from a Streptomyces griseus strain cultured from the soils of Antarctica [17].

Angucyclinone natural products have been isolated from a variety of actinobacteria since the discovery of tetrangomycin and tetrangulol in the 1960s, and congeners of this increasingly diverse natural product class have exhibited intriguing activity profiles [10,11,18]. Frigocyclinone (1) was the first angucyclinone derivative to have a $C$-glycosidic linked aminodeoxy sugar moiety (Figure 1 ). In this study we report six related derivatives, called the monacyclinones, which contain similar features to frigocyclinone including the characteristic $C$-glycosidic aminodeoxy sugar moiety. Significantly, the wild-type strain also produces monacyclinone D (7) in which the A ring is found as a lactone moiety, which most likely arises by a Baeyer-Villiger reaction. In addition, this compound co-occurs with the open chain hydrolysis product monacyclinone E (8). Monacyclinone F (9) contains two epoxide rings attached to the angucyclinone moiety and an additional aminodeoxysugar unit, but this time attached by an ether linkage (Figure 1). These novel compounds displayed biological activity against human rhabdomyosarcoma cancer cells (SJCRH30) and gram-positive bacteria.

\section{Results and Discussion}

\subsection{Purification and Structure Elucidation of Angucyclinone Derivatives}

Frigocyclinone (1) was previously isolated and characterized from a species of Streptomyces griseus isolated from soils of Antarctica [17]. This compound has a very unusual $C$-glycosidic linked aminodeoxy sugar moiety attached to an anthraquinone chromophore that displays a characteristic UV absorption spectrum. Upon analysis of the liquid chromatography-diode array detection-electrospray ionization mass spectrometry (LC-DAD-ESIMS) data of fractions from Streptomyces sp. strain M7_15, the 80\%-100\% $\mathrm{MeOH}$ fractions showed a UV absorbance spectrum similar to frigocyclinone (287, 314, and $405 \mathrm{~nm}$ ). Further purification of this fraction yielded $13 \mathrm{mg}$ of a compound with a molecular weight of $463 \mathrm{Da}$. 
Structural characterization of this compound following ${ }^{1} \mathrm{H}$ NMR and ${ }^{13} \mathrm{C}$ NMR $1 \mathrm{D}$ and 2D experiments established that the ${ }^{1} \mathrm{H}$ NMR and ${ }^{13} \mathrm{C}$ NMR signals were consistent with those reported for frigocyclinone (Table S1). In addition, high-resolution electrospray ionization mass spectrometry (HRESIMS) showed a pseudomolecular ion at $\mathrm{m} / z$ 464.2061 $[\mathrm{M}+\mathrm{H}]^{+}$suggesting a molecular formula of $\mathrm{C}_{27} \mathrm{H}_{30} \mathrm{NO}_{6}$ (calculated: $464.2073, \Delta_{\mathrm{m}}=-2.6 \mathrm{ppm}$ ), consistent with (1).
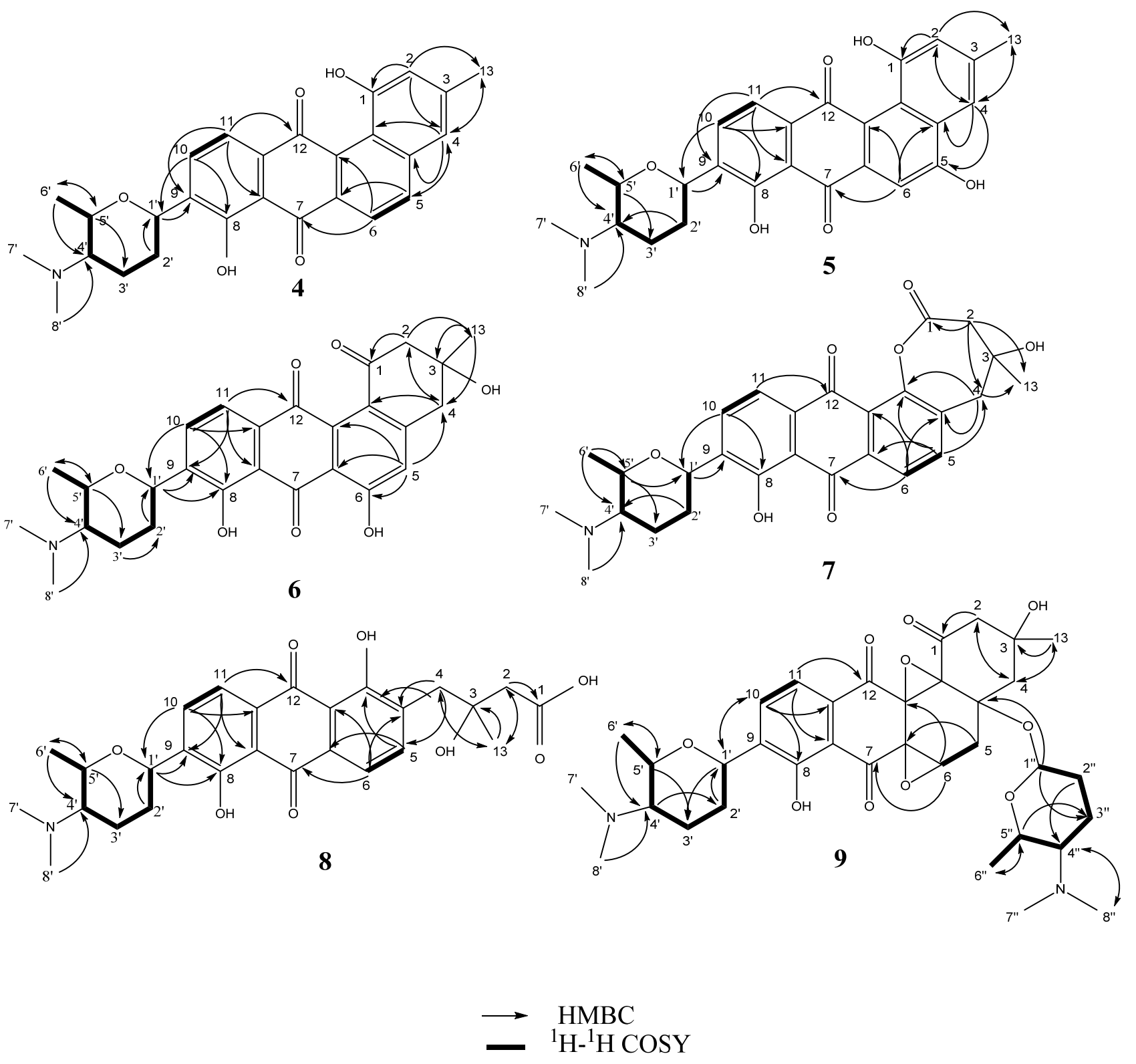

Figure 1. Key ${ }^{1} \mathrm{H}-{ }^{1} \mathrm{H}$ COSY and HMBC correlations of compounds 4-9.

Dimethyldehydrorabelomycin $(\mathbf{3}, 3.2 \mathrm{mg})$ was isolated as a red amorphous powder from the frigocyclinone-containing fraction. An HRESIMS measurement of $[\mathrm{M}+\mathrm{H}]^{+}$at $m / z 349.1071$ suggested the molecular formula $\mathrm{C}_{21} \mathrm{H}_{17} \mathrm{O}_{5}$ (calculated: $m / z$ 349.1076, $\Delta_{\mathrm{m}}=-1.4 \mathrm{ppm}$ ) indicating 14 double bond equivalents (Table S2). The UV spectrum of compound $\mathbf{3}$ in pyridine exhibited maximum absorbance at 290, 318, and $415 \mathrm{~nm}$, indicative of a substituted anthraquinone moiety. Compound $\mathbf{3}$ was previously obtained by exposing dehydrorabelomycin (2) [19], to the methyltransferase enzyme GilMT [20]. 
Comparison of all ${ }^{1} \mathrm{H}$ NMR and ${ }^{13} \mathrm{C}$ NMR data for 3 were in agreement with those reported by Tibrewal et al. [20] (Table S2).

Monacyclinone A (4, 4.3 mg) was isolated as a yellow powder and was calculated to have a molecular formula of $\mathrm{C}_{27} \mathrm{H}_{28} \mathrm{NO}_{5}\left([\mathrm{M}+\mathrm{H}]^{+}\right.$observed: $m / z$ 446.1974, calculated: $m / z 446.1967, \Delta_{\mathrm{m}}=1.6 \mathrm{ppm}$ ) as determined by HRESIMS, and corresponding to an additional double bond equivalent compared with 1 (Figure 2), and a possible loss of $\mathrm{H}_{2} \mathrm{O}$. The UV spectrum of compound 4 in pyridine exhibited maximum absorbance at 280, 315, and $422 \mathrm{~nm}$. Analysis of the ${ }^{1} \mathrm{H}$ and ${ }^{13} \mathrm{C}$ NMR spectral data for 4 (Table 1) showed many similarities with the chemical shift values corresponding to the frigocyclinone sugar moiety, which was attached to the aromatic nucleus at C-9 based on an HMBC correlation between H-1' and C-9 (Figure 1 and Table S3). Resonances for the two pairs of aromatic protons on the B ring $\left(\mathrm{H}-5 \delta_{\mathrm{H}} 8.19 \mathrm{~d}, J=8 \mathrm{~Hz} ; \mathrm{H}-6 \delta_{\mathrm{H}} 8.40 \mathrm{~d}, J=8 \mathrm{~Hz}\right)$ and the $\mathrm{D}$ ring $\left(\mathrm{H}-10 \delta_{\mathrm{H}} 8.03 \mathrm{~d}, J=8 \mathrm{~Hz} ; \mathrm{H}-11 \delta_{\mathrm{H}}\right.$ $7.91 \mathrm{~d}, J=8 \mathrm{~Hz}$ ) were consistent with those observed in the ${ }^{1} \mathrm{H}$ spectrum of $\mathbf{1}$ (Table 1, Figure 2). The chemical shifts of the A ring aromatic protons $\left(\mathrm{H}-2 \delta_{\mathrm{H}} 7.33 \mathrm{~s} ; \mathrm{H}-4 \delta_{\mathrm{H}} 7.28 \mathrm{~s}\right)$ were consistent with those of dehydrorabelomycin (2). The assignment of the relative configuration at carbons C-1', C-4', C-5' was based on intense ROESY cross peaks between protons $\mathrm{H}-1^{\prime}\left(\delta_{\mathrm{H}} 5.26_{\mathrm{ax}}\right), \mathrm{H}-3^{\prime}$ at $\left(\delta_{\mathrm{H}} 1.98_{\mathrm{ax}}\right)$, and $\mathrm{H}-6^{\prime}$ at $\left(\delta_{\mathrm{H}} 1.52_{\mathrm{ax}}\right)$ which positions these protons on the same side of the angucyclinone moiety (Table S3; Figure 3). Additionally, ROESY cross peaks between proton $\mathrm{H}-2^{\prime}{ }_{\mathrm{ax}}\left(\delta_{\mathrm{H}} 1.44\right)$ and $\mathrm{H}-4^{\prime}{ }_{\mathrm{ax}}$ at $\left(\delta_{\mathrm{H}} 2.82\right)$ indicated diaxial interactions on the opposite face of the sugar ring (Figure 3 ).

Monacyclinone B (5, $7.4 \mathrm{mg})$ was isolated as an orange powder and was calculated to have a molecular formula of $\mathrm{C}_{27} \mathrm{H}_{28} \mathrm{NO}_{6}\left([\mathrm{M}+\mathrm{H}]^{+}\right.$observed: $m / z$ 462.1917, calculated: $m / z$ 462.1917, $\Delta_{\mathrm{m}} 0.0 \mathrm{ppm}$ ) corresponding to an additional oxygen compared with $\mathbf{4}$, and shared a similar UV absorption spectrum (299, 328, and $445 \mathrm{~nm})$. The difference in molecular formulae suggested $\mathbf{5}$ contained an additional phenolic group as indicated by the appearance of a new quaternary carbon shift at $\delta 157.4$ in the ${ }^{13} \mathrm{C}$ NMR spectrum (Table 1). An HMBC correlation from the singlet aromatic proton at $\left(\mathrm{H}-6, \delta_{\mathrm{H}} 8.01\right)$ to $\mathrm{C}-4 \mathrm{a}\left(\delta_{\mathrm{C}} 124.2\right)$ and $\mathrm{C}-7\left(\delta_{\mathrm{C}} 189.9\right)$ implied that the phenolic substituent resided on $\mathrm{C}-5$, and further evidenced by the upfield shift of the aromatic proton at C-6 $\left(\delta_{C} 105.6\right)$ in 5 when compared to 4. Comparison of the ${ }^{1} \mathrm{H}$ and ${ }^{13} \mathrm{C}$ NMR signals for the rest of the molecule with those observed for 4 supported the proposed structure (Table S4), including the presence of the aminodeoxy sugar with identical configuration to the corresponding moiety in 4.

The molecular formula of monacyclinone $\mathrm{C}(6,1.5 \mathrm{mg})\left(\mathrm{C}_{27} \mathrm{H}_{30} \mathrm{NO}_{7}[\mathrm{M}+\mathrm{H}]^{+}\right.$, observed: $\mathrm{m} / \mathrm{z}$ 480.2027, calculated: $\mathrm{m} / \mathrm{z} 480.2022, \Delta_{\mathrm{m}}=1.0 \mathrm{ppm}$ ) indicated 14 double bond equivalents and an additional oxygen atom compared with frigocyclinone (1) (Figure 2). This was consistent with the UV spectrum of 6 which showed absorption maxima at 280, 301 and 429 in accordance with the UV absorption profile of frigocyclinone (1). Much of the 1D and 2D NMR data for $\mathbf{6}$ was identical to 1: For example, the characteristic C-1 carbonyl shift at $\delta_{\mathrm{C}} 196.9$, as well as HMBC correlations between the two methylene groups at $\mathrm{C}-2\left(\mathrm{CH}_{2} \delta_{\mathrm{H}} 3.22 \mathrm{~m}, 2 \mathrm{H}\right)$ and $\mathrm{C}-4\left(\mathrm{CH}_{2} \delta_{\mathrm{H}} 3.25 \mathrm{~m}, 2 \mathrm{H}\right)$ with the methyl substituent at $\mathrm{C}-3\left(\delta_{\mathrm{H}} 1.56 \mathrm{~s}, 3 \mathrm{H} ; \delta_{\mathrm{C}} 30.1\right)$ (Figure 3 ), indicated that ring A was unchanged (Table 1, Figure 2). In addition, the usual 1D and 2D NMR data established an aminodeoxysugar group attached to C-9 of the anthraquinone moiety (Table S5). Similar to monacyclinone B (5), the ${ }^{1} \mathrm{H}$ NMR data of 6 (Table 1) showed the loss of an aryl proton, while the ${ }^{13} \mathrm{C}$ NMR spectrum now contained a quaternary carbon at $\delta_{\mathrm{C}} 164.5$ consistent with a phenolic substituent. However in contrast to 5, HMBC correlations in the B 
ring of 6 were observed from the singlet aromatic proton $\mathrm{H}-5\left(\delta_{\mathrm{H}} 7.16\right)$ to $\mathrm{C}-4\left(\delta_{\mathrm{C}} 45.0\right)$ and C-6 $(\delta \mathrm{c} 164.5)$, indicating that the phenolic group resided on C-6.

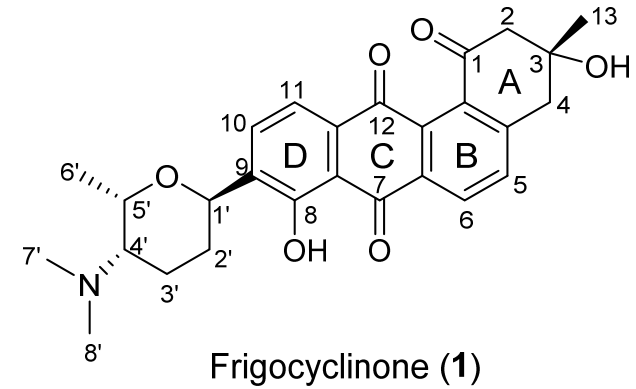

Frigocyclinone (1)<smiles>Cc1cc(O)c2c3c(c(O)cc2c1)C(=O)c1cccc(O)c1C3=O</smiles>

Dehydrorabelomycin (2)<smiles>[Y3]Oc1cccc2c1C(=O)c1c(O)cc3cc(C)cc(O[Y5])c3c1C2=O</smiles>

Dimethyldehydrorabelomycin (3)<smiles>Cc1cc(O)c2c3c(ccc2c1)C(=O)c1c(ccc([C@H]2CC[C@H](N(C)C)[C@H](C)O2)c1O)C3=O</smiles>

Monacyclinone A (4)<smiles>Cc1cc(O)c2c3c(cc(O)c2c1)C(=O)c1c(ccc([C@H]2CC[C@H](N(C)C)[C@H](C)O2)c1O)C3=O</smiles>

Monacyclinone B (5)<smiles>C[C@H]1O[C@@H](c2ccc3c(c2O)C(=O)c2c(O)cc4c(c2C3=O)C(=O)C[C@](C)(O)C4)CC[C@@H]1N(C)C</smiles>

Monacyclinone C (6)

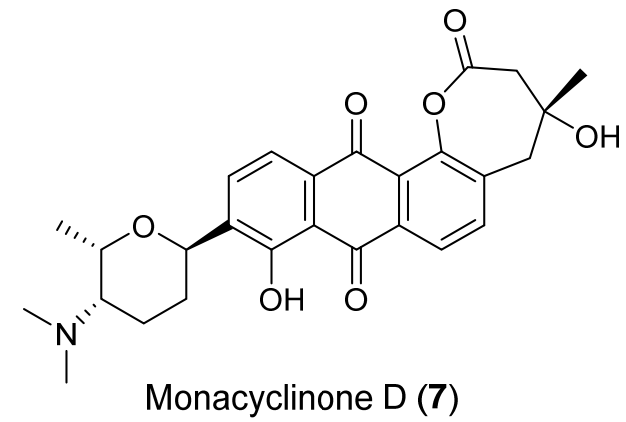<smiles>C[C@H]1O[C@@H](c2ccc3c(c2O)C(=O)c2ccc(C[C@](C)(O)CC(=O)O)c(O)c2C3=O)CC[C@@H]1N(C)C</smiles>

Monacyclinone $\mathrm{E}(\mathbf{8})$

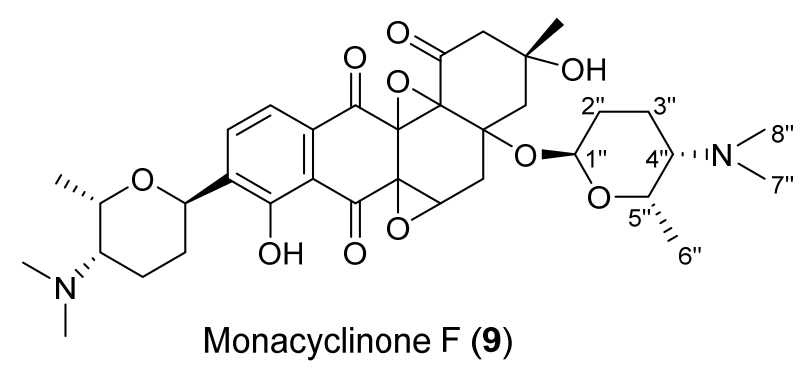

Figure 2. Monacyclinone derivatives isolated from Streptomyces sp. M7_15 including previously described frigocyclinone and dehydrorabelomycin. 
A

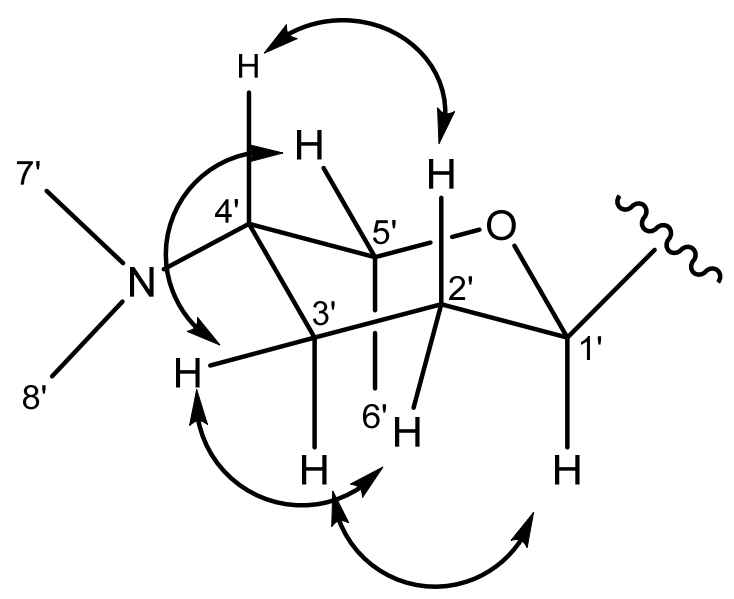

B

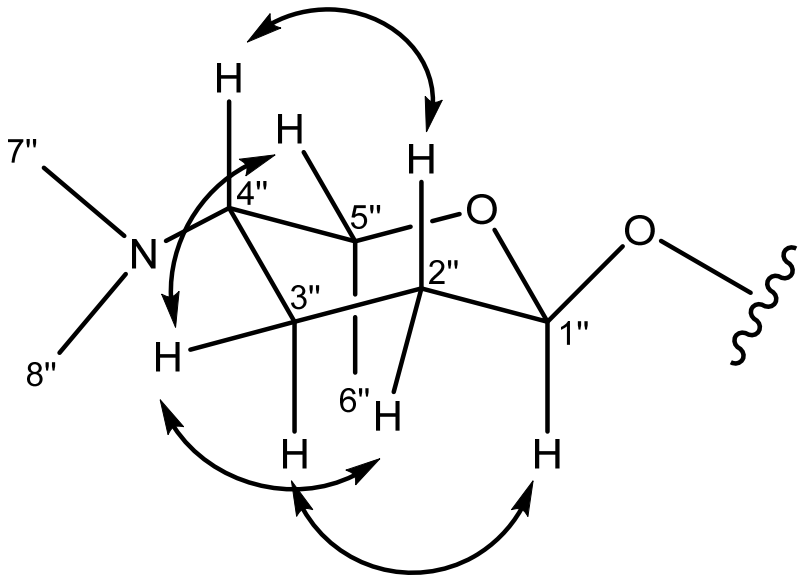

Figure 3. ROESY correlations for the $C$-linked aminodeoxysugar of compounds 4-8 (A) ROESY correlations for the $O$-linked aminodeoxysugar of compound 9 (B).

Table $1 .{ }^{13} \mathrm{C}$ and ${ }^{1} \mathrm{H}$ NMR data for compounds $4,5,6,7,8$ (in pyridine- $d_{5}$ ).

\begin{tabular}{|c|c|c|c|c|c|c|c|c|c|c|}
\hline \multirow[b]{2}{*}{ Position } & \multicolumn{2}{|c|}{ Monacyclinone A (4) } & \multicolumn{2}{|c|}{ Monacyclinone B (5) } & \multicolumn{2}{|c|}{ Monacyclinone C (6) } & \multicolumn{2}{|c|}{ Monacyclinone D (7) } & \multicolumn{2}{|c|}{ Monacyclinone E (8) } \\
\hline & ${ }^{13} \mathrm{C}$ & $\begin{array}{c}{ }^{1} \mathrm{H} \\
(\mathrm{m}, J \mathrm{~Hz}) \\
\end{array}$ & ${ }^{13} \mathrm{C}$ & $\begin{array}{c}{ }^{1} \mathbf{H} \\
(\mathrm{m}, J \mathrm{~Hz}) \\
\end{array}$ & ${ }^{13} \mathrm{C}$ & $\begin{array}{c}{ }^{1} \mathbf{H} \\
(\mathrm{m}, J \mathbf{H z}) \\
\end{array}$ & ${ }^{13} \mathrm{C}$ & $\begin{array}{c}{ }^{1} \mathrm{H} \\
(\mathrm{m}, J \mathrm{~Hz}) \\
\end{array}$ & ${ }^{13} \mathrm{C}$ & $\begin{array}{c}{ }^{1} \mathbf{H} \\
(\mathbf{m}, J \mathbf{H z}) \\
\end{array}$ \\
\hline 1 & 156.7 & & 164.8 & & 196.9 & & 172.9 & & 175.7 & \\
\hline \multirow[t]{2}{*}{2} & 119.9 & $7.33(\mathrm{~s})$ & 116.0 & $8.22(\mathrm{~s})$ & 54.5 & $3.22(\mathrm{~m})$ & 45.3 & $3.23(\mathrm{~d}, 17.0)$ & 46.9 & $3.02(\mathrm{~m})$ \\
\hline & & & & & & $3.22(\mathrm{~m})$ & & $3.21(\mathrm{~d}, 17.0)$ & & $3.02(\mathrm{~m})$ \\
\hline 3 & 142.6 & & 141.5 & & 71.9 & & 90.7 & & 72.4 & \\
\hline \multirow[t]{2}{*}{4} & 121.6 & $7.28(\mathrm{~s})$ & 121.0 & $7.43(\mathrm{~s})$ & 45.0 & $3.25(\mathrm{~m})$ & 40.3 & $3.21(\mathrm{~d}, 17.0)$ & 41.0 & $2.52(\mathrm{~m})$ \\
\hline & & & & & & $3.25(\mathrm{~m})$ & & $3.81(\mathrm{~d}, 17.0)$ & & $3.47(\mathrm{~m})$ \\
\hline $4 a$ & 120.3 & & 124.2 & & 153.6 & & 139.4 & & 136.7 & \\
\hline 5 & 137.5 & $8.19(\mathrm{~d}, 8.0)$ & 157.4 & & 122.4 & $7.16(\mathrm{~s})$ & 130.5 & $7.53(\mathrm{~d}, 8.0)$ & 140.7 & $8.06(\mathrm{~d}, 8.0)$ \\
\hline 6 & 122.5 & $8.40(\mathrm{~d}, 8.0)$ & 105.6 & $8.01(\mathrm{~s})$ & 164.5 & & 120.8 & $8.01(\mathrm{~d}, 8.0)$ & 118.9 & $7.90(\mathrm{~d}, 8.0)$ \\
\hline $6 a$ & 135.6 & & 123.5 & & 117.5 & & 133.4 & & 132.4 & \\
\hline 7 & 188.1 & & 189.9 & & 193.1 & & 189.6 & & 188.9 & \\
\hline $7 \mathrm{a}$ & 115.0 & & 115.2 & & 115.4 & & 115.9 & & 116.3 & \\
\hline 8 & 158.7 & & 158.9 & & 158.8 & & 159.2 & & 160.0 & \\
\hline 9 & 140.0 & & 139.9 & & 139.0 & & 138.2 & & 141.0 & \\
\hline 10 & 134.1 & $8.03(\mathrm{~d}, 8.0)$ & 134.0 & $8.05(\mathrm{~d}, 8.0)$ & 134.5 & $8.03(\mathrm{~d}, 8.0)$ & 133.7 & $8.09(\mathrm{~d}, 8.0)$ & 134.0 & $8.13(\mathrm{~d}, 8.0)$ \\
\hline 11 & 121.4 & $7.91(\mathrm{~d}, 8.0)$ & 121.3 & $7.97(\mathrm{~d}, 8.0)$ & 119.5 & $7.82(\mathrm{~d}, 8.0)$ & 119.0 & $8.05(\mathrm{~d}, 8.0)$ & 119.6 & $8.00(\mathrm{~d}, 8.0)$ \\
\hline $11 \mathrm{a}$ & 134.6 & & 135.1 & & 135.3 & & 133.4 & & 132.6 & \\
\hline 12 & 189.5 & & 187.5 & & 184.1 & & 181.0 & & 189.1 & \\
\hline $12 \mathrm{a}$ & 134.3 & & 132.2 & & 130.6 & & 116.7 & & 116.3 & \\
\hline $12 \mathrm{~b}$ & 121.1 & & 123.7 & & 122.6 & & 160.0 & & 162.6 & \\
\hline 13 & 21.5 & $2.39(\mathrm{~s})$ & 21.7 & $2.46(\mathrm{~s})$ & 30.1 & $1.56(\mathrm{~s})$ & 27.3 & $1.78(\mathrm{~s})$ & 27.8 & $1.69(\mathrm{~s})$ \\
\hline $1^{\prime}$ & 65.2 & $5.26_{\mathrm{ax}}(\mathrm{d}, 11.0)$ & 65.2 & $5.23_{\mathrm{ax}}(\mathrm{m})$ & 65.1 & $\begin{array}{c}5.22_{\mathrm{ax}} \\
(\mathrm{dd}, 11.0,1.0)\end{array}$ & 64.7 & $5.26_{\mathrm{ax}}(\mathrm{m})$ & 65.2 & $5.25_{\mathrm{ax}}(\mathrm{m})$ \\
\hline $2^{\prime}$ & 32.5 & $1.44_{\mathrm{ax}}(\mathrm{m})$ & 32.5 & $1.44_{\mathrm{ax}}(\mathrm{m})$ & 32.1 & $1.36_{\mathrm{ax}}(\mathrm{m})$ & 31.9 & $1.39_{\mathrm{ax}}(\mathrm{m})$ & 32.2 & $1.42_{\mathrm{ax}}(\mathrm{m})$ \\
\hline & & $2.39_{\mathrm{eq}}(\mathrm{m})$ & & $2.30_{\mathrm{eq}}(\mathrm{m})$ & & $2.34_{\mathrm{eq}}(\mathrm{m})$ & & $2.33_{\mathrm{eq}}(\mathrm{m})$ & & $2.33_{\mathrm{eq}}(\mathrm{m})$ \\
\hline
\end{tabular}


Table 1. Cont.

\begin{tabular}{|c|c|c|c|c|c|c|c|c|c|c|}
\hline \multirow[t]{2}{*}{$3^{\prime}$} & 22.4 & $1.98_{\mathrm{ax}}(\mathrm{m})$ & 22.8 & $1.79_{\mathrm{ax}}(\mathrm{m})$ & 22.7 & $1.81_{\mathrm{ax}}(\mathrm{m})$ & 22.5 & $1.83_{\mathrm{ax}}(\mathrm{m})$ & 23.1 & $1.69_{\mathrm{ax}}(\mathrm{m})$ \\
\hline & & $1.98_{\mathrm{eq}}(\mathrm{m})$ & & $1.93_{\mathrm{eq}}(\mathrm{m})$ & & $1.94_{\mathrm{eq}}(\mathrm{m})$ & & $1.94_{\mathrm{eq}}(\mathrm{m})$ & & $1.89_{\mathrm{eq}}(\mathrm{m})$ \\
\hline $4^{\prime}$ & 64.7 & $2.82_{\mathrm{ax}}($ br s $)$ & 64.5 & $2.53_{\mathrm{ax}}(\mathrm{s})$ & 64.7 & $2.53_{\mathrm{ax}}(\mathrm{m})$ & 64.2 & $2.54_{\mathrm{ax}}(\mathrm{m})$ & 64.7 & $2.33_{\mathrm{ax}}(\mathrm{m})$ \\
\hline $5^{\prime}$ & 71.2 & $4.72(\mathrm{~m})$ & 71.6 & $4.64(\mathrm{~m})$ & 71.9 & $4.61(\mathrm{~m})$ & 71.8 & $4.63(\mathrm{~m})$ & 72.0 & $4.61(\mathrm{~m})$ \\
\hline $6^{\prime}$ & 12.4 & $1.52_{\mathrm{ax}}(\mathrm{d}, 7.0)$ & 12.2 & $1.44_{\mathrm{ax}}(\mathrm{m})$ & 12.3 & $1.44_{\mathrm{ax}}(\mathrm{d}, 7.0)$ & 12.0 & $1.46_{\mathrm{ax}}(\mathrm{d}, 7.0)$ & 12.3 & $1.42_{\mathrm{ax}}(\mathrm{m})$ \\
\hline $7^{\prime}$ & 42.8 & $2.52(\mathrm{~s})$ & 43.2 & $2.31(\mathrm{~s})$ & 43.0 & $2.34(\mathrm{~s})$ & 43.0 & $2.33(\mathrm{~s})$ & 43.3 & $2.19(\mathrm{~s})$ \\
\hline $8^{\prime}$ & 42.8 & $2.52(\mathrm{~s})$ & 43.2 & $2.31(\mathrm{~s})$ & 43.0 & $2.34(\mathrm{~s})$ & 43.0 & $2.33(\mathrm{~s})$ & 43.3 & $2.19(\mathrm{~s})$ \\
\hline
\end{tabular}

Monacyclinone D (7, $2.2 \mathrm{mg})$ was isolated as a bright yellow powder and the molecular formula of $\mathrm{C}_{27} \mathrm{H}_{30} \mathrm{NO}_{7}\left([\mathrm{M}+\mathrm{H}]^{+}\right.$observed: $m / z$ 480.2022, calculated: $m / z$ 480.2022, $\Delta_{\mathrm{m}}=0.0 \mathrm{ppm}$ ) was determined by HRESIMS indicating 14 double bond equivalents. Although 7 was found to have the identical molecular formula of $\mathbf{6}$, several notable differences were found in the NMR spectra of 7 compared to $\mathbf{6}$. The ${ }^{1} \mathrm{H}$ and ${ }^{13} \mathrm{C}$ NMR spectral data of 7 (Table 1) showed the presence of four aromatic protons $\left(\delta_{\mathrm{H}} 7.53\right.$, $\left.1 \mathrm{H}, \mathrm{d}, J=8 \mathrm{~Hz} ; \delta_{\mathrm{H}} 8.01,1 \mathrm{H}, \mathrm{d}, J=8 \mathrm{~Hz} ; \delta_{\mathrm{H}} 8.05,1 \mathrm{H}, \mathrm{d}, J=8 \mathrm{~Hz} ; \delta_{\mathrm{H}} 8.09,1 \mathrm{H}, \mathrm{d}, J=8 \mathrm{~Hz}\right)$. Most significantly, the ${ }^{1} \mathrm{H}$ NMR data revealed that $\mathrm{H}-5$ now appeared as a doublet $\left(\delta_{\mathrm{H}} 7.53, J=8 \mathrm{~Hz}\right)$ and was coupled with a proton at $\mathrm{H}-6\left(\delta_{\mathrm{H}} 8.05, \mathrm{~d}, J=8 \mathrm{~Hz}\right)$, as seen in $\mathbf{1}$ and $\mathbf{4}$. Additionally the ${ }^{13} \mathrm{C}$ spectrum showed that $\mathrm{C}-12 \mathrm{~b}$ was considerably deshielded in 7 (Table 1), consistent with an oxygen atom bonded to this carbon. A significant difference was observed in the chemical shift of the C-1 carbonyl in $7\left(\delta_{\mathrm{C}} 172.9\right)$ compared with $6\left(\delta_{\mathrm{C}} 196.9\right)$, suggesting the presence of an ester or carboxylic acid functionality. In addition, 7 also contained the two methylene groups both of which appeared as an AB quartet (C-2: $\mathrm{CH}_{2} \delta_{\mathrm{H}} 3.21 \mathrm{~d}, J=17 \mathrm{~Hz}, 3.23 \mathrm{~d}, J=17 \mathrm{~Hz}$ and $\mathrm{C}-4: \mathrm{CH}_{2} \delta_{\mathrm{H}} 3.21 \mathrm{~d}, J=17 \mathrm{~Hz}, 3.81 \mathrm{~d}$, $J=17 \mathrm{~Hz}$ ). Both also displayed HMBC correlations with the methyl substituent at C-3 as observed with 6 (Table S6; Figure 1). These results, in addition to the double bond equivalents calculated from the molecular formula, indicated that 7 contains a seven membered lactone ring formed by a Baeyer Villiger oxygenation reaction [21]. A similar angucyclinone containing a lactone moiety was identified in trace amounts from a mutant strain of $S$. fradiae [22], but our work represents the first report of such a compound obtained from a wild-type strain.

Many of the NMR spectral features of monacyclinone E $(\mathbf{8}, 1.8 \mathrm{mg})\left(\mathrm{C}_{27} \mathrm{H}_{32} \mathrm{NO}\right.$, $[\mathrm{M}+\mathrm{H}]^{+}$observed: $\mathrm{m} / \mathrm{z}$ 498.2124, calculated: $\mathrm{m} / \mathrm{z} 498.2128, \Delta_{\mathrm{m}}=-0.8 \mathrm{ppm}$ ) were similar to those of frigocyclinone (1) and monacyclinone D (7). The ${ }^{1} \mathrm{H}$ and ${ }^{13} \mathrm{C}$ NMR 2D spectral data of 8 (Tables 1 and S7) indicated no changes to the aminodeoxysugar substituent, including the point of attachment at C-9 as indicated by an HMBC correlation between the aromatic carbon C-9 $\left(\delta_{\mathrm{C}} 141.0\right)$ and the anomeric proton $\mathrm{H}-1^{\prime}\left(\delta_{\mathrm{H}} 5.22 \mathrm{~m}\right)$. The other spectral data (Table 1) revealed four aromatic protons $\mathrm{H}-5\left(\delta_{\mathrm{H}} 8.06 \mathrm{~d}, J=8 \mathrm{~Hz}\right), \mathrm{H}-6\left(\delta_{\mathrm{H}} 7.90 \mathrm{~d}\right.$, $J=8 \mathrm{~Hz}), \mathrm{H}-10\left(\delta_{\mathrm{H}} 8.13 \mathrm{~d}, J=8 \mathrm{~Hz}\right)$, and $\mathrm{H}-11\left(\delta_{\mathrm{H}} 8.0 \mathrm{~d}, J=8 \mathrm{~Hz}\right)$, on rings B and D respectively establishing the same substitution pattern as found in $\mathbf{1}, \mathbf{4}$, and 7 . The ${ }^{13} \mathrm{C}$ resonance for $\mathrm{C}-1$ was observed at a higher field in 8 ( $\left.\delta_{\mathrm{C}} 175.7\right)$ compared with 6 ( $\left.\delta_{\mathrm{C}} 196.9\right)$ (Table 1$)$ and the chemical shift for $\mathrm{C}-12 \mathrm{~b}$ appeared at $\delta_{\mathrm{C}} 162.6$, both of which suggested similarity to 7 . Based on these chemical shift changes, the loss of one double bond equivalent indicated by the molecular formula revealed that $\mathbf{8}$ was the result of an oxidative opening of the lactone ring in 7. A similar ring opening has been observed in fridamycin D [8].

Metabolites 4-8 shared similar structural features with the previously reported frigocyclinone and dehydrorabelomycin. In all compounds the aminodeoxysugar was present and attached through a 
$C$-glycosidic bond to the C-9 of the angucyclinone chromophore. However, an additional metabolite (compound 9) was isolated from the fermentation extract and found to have a second aminodeoxy sugar attached through an angular oxygen to the angucyclinone chromophore.

Monacyclinone F (9,8.3 $\mathrm{mg})$ was isolated as a purple oil and found to have the molecular formula $\mathrm{C}_{35} \mathrm{H}_{47} \mathrm{~N}_{2} \mathrm{O}_{10}\left([\mathrm{M}+\mathrm{H}]^{+}\right.$observed: $m / z$ 655.3253, calculated: $m / z$ 655.3231, $\left.\Delta_{\mathrm{m}}=3.4 \mathrm{ppm}\right)$ by HRESIMS indicating 14 double bond equivalents (Figure 2). The UV absorption spectrum of 9 showed absorption maxima at 281, 298, and $367 \mathrm{~nm}$. The ${ }^{1} \mathrm{H}$ and ${ }^{13} \mathrm{C}$ NMR spectral data of 9 (Table 2) showed the presence of only two ortho coupled aromatic protons $\mathrm{H}-10\left(\delta_{\mathrm{H}} 8.14 \mathrm{~d}, J=8 \mathrm{~Hz}\right)$ and $\mathrm{H}-11\left(\delta_{\mathrm{H}} 8.03 \mathrm{~d}, J=8 \mathrm{~Hz}\right)$, consistent with a C/D ring system as found in $\mathbf{1}$ and 4-8 (Figure 2, Table 2). Once again, the chemical shift data established an aminodeoxy sugar attached in the usual fashion to C-9 of ring D as well as a phenolic group at C-8 ( $\left.\delta_{C} 159.2\right)$. In contrast, the protons at C-5 and C-6 now appeared as a methylene group $\delta_{\mathrm{H}} 2.83(\mathrm{~m})$ and a methine $\delta_{\mathrm{H}} 4.69(\mathrm{~m})$, respectively. Furthermore, the upfield chemical shift of the carbons in ring B $\left(\mathrm{C}-4 \mathrm{a}\left(\delta_{\mathrm{C}} 82.8\right), \mathrm{C}-5\left(\delta_{\mathrm{C}} 36.7\right), \mathrm{C}-6\left(\delta_{\mathrm{C}} 64.5\right), \mathrm{C}-6 \mathrm{a}\left(\delta_{\mathrm{C}} 58.5\right), \mathrm{C}-12 \mathrm{a}\left(\delta_{\mathrm{C}} 71.3\right)\right.$, and $\mathrm{C}-12 \mathrm{~b}\left(\delta_{\mathrm{C}} 80.5\right)$, established a loss of aromaticity in this ring. Thus the number of double bond equivalents must be accounted for as rings, and based on analysis of HMBC and HSQC NMR data (Table 2, Figures S18 and S19) it was found that two of the additional oxygen atoms in the molecular formula of 9 could be accounted for as epoxide rings. One of the epoxide rings included carbons C-6 $\left(\delta_{\mathrm{C}} 64.5\right)$ and $\mathrm{C}-6 \mathrm{a}\left(\delta_{\mathrm{C}} 58.5\right)$, while the second contained carbons $\mathrm{C}-12 \mathrm{a}\left(\delta_{\mathrm{C}} 71.3\right)$ and $\mathrm{C}-12 \mathrm{~b}\left(\delta_{\mathrm{C}} 80.5\right)$ (Table 2, Figure 1, Table S8). Further HMBC analysis revealed a strong correlation between C-4a $\left(\delta_{\mathrm{C}} 82.8\right)$ and the anomeric proton $\mathrm{H}-1$ " $\left(\delta_{\mathrm{H}} 5.75 \mathrm{~s}\right)$, identifying the presence of a second aminodeoxysugar (Table S8), thus accounting for the final double bond equivalent. The chemical shift of the anomeric carbon $\mathrm{C}-1$ " $\left(\delta_{\mathrm{C}} 94.1\right)$ indicated that this sugar moiety was attached to the central core through a more common ether link and not through a $C$-glycosydic bond. There were no other significant changes to ring $\mathrm{A}$ as suggested by the presence of the two methylene groups at $\mathrm{C}-2\left(\mathrm{CH}_{2} \delta_{\mathrm{H}} 2.83 \mathrm{dd} J=18,3 \mathrm{~Hz}\right.$, $\left.\delta_{\mathrm{H}} 3.34 \mathrm{dd} J=18,3 \mathrm{~Hz}\right)$ and $\mathrm{C}-4\left(\mathrm{CH}_{2} \delta_{\mathrm{H}} 2.12 \mathrm{~m}, 2.93 \mathrm{dd} J=14,3 \mathrm{~Hz}\right)$ that showed HMBC correlations with the methyl substituent at C-3 (Table 2; Table S8; Figure 1). The relative configuration of both aminodeoxy sugar moieties were found to be identical to that observed in frigocyclinone based on ROESY correlations between the axial hydrogen atoms as described above (Figures 1 and 3).

Table 2. ${ }^{13} \mathrm{C}$ and ${ }^{1} \mathrm{H}$ NMR data for compound 9 (in pyridine- $d_{5}$ ).

\begin{tabular}{|c|c|c|c|c|c|c|}
\hline Position & ${ }^{13} \mathrm{C}$ & ${ }^{1} \mathrm{H}(\mathrm{m}, J \mathrm{~Hz})$ & COSY & HMBC & ROESY & TOCSY \\
\hline 1 & $204.4, \mathrm{C}$ & & & & & \\
\hline \multirow[t]{2}{*}{2} & $50.6, \mathrm{C}$ & $2.83(\mathrm{dd}, 18.0,3.0)$ & & $4,12 \mathrm{a}, 4 \mathrm{a}, 1,13,3$ & 4 & \\
\hline & & $3.34(\mathrm{dd}, 18.0,3.0)$ & & & & \\
\hline 3 & 75.9, C & & & & & \\
\hline \multirow[t]{2}{*}{4} & $49.8, \mathrm{CH}_{2}$ & $2.12(\mathrm{~m})$ & & $13,5,3,2$ & 2 & \\
\hline & & $2.93(\mathrm{dd}, 14.0,3.0)$ & & & & \\
\hline $4 a$ & $82.8, \mathrm{C}$ & & & & & \\
\hline 5 & $36.7, \mathrm{CH}_{2}$ & $2.83(\mathrm{~m})$ & 6 & $7 \mathrm{a}, 6,12 \mathrm{a}, 4 \mathrm{a}, 1$ & & 6 \\
\hline 6 & $64.5, \mathrm{CH}$ & $4.69(\mathrm{~m})$ & 5 & & & \\
\hline $6 a$ & $58.5, \mathrm{C}$ & & & & & \\
\hline 7 & 198.0, C & & & & & \\
\hline $7 \mathrm{a}$ & $118.4, \mathrm{C}$ & & & & & \\
\hline
\end{tabular}


Table 2. Cont.

\begin{tabular}{|c|c|c|c|c|c|c|}
\hline 8 & $159.2, \mathrm{C}$ & & & & & \\
\hline 9 & $140.7, \mathrm{C}$ & & & & & \\
\hline 10 & $135.3, \mathrm{CH}$ & $8.14(\mathrm{~d}, 8.0)$ & 11 & $1^{\prime}, 7 \mathrm{a}, 11,11 \mathrm{a}, 8$ & & 11 \\
\hline 11 & $120.5, \mathrm{CH}$ & $8.03(\mathrm{~d}, 8.0)$ & 10 & $7 a, 9,8,12,7$ & & 10 \\
\hline $11 \mathrm{a}$ & 133.1, C & & & & & \\
\hline 12 & 192.7, C & & & & & \\
\hline $12 \mathrm{a}$ & 71.3, C & & & & & \\
\hline $12 b$ & $80.5, \mathrm{C}$ & & & & & \\
\hline 13 & $25.7 \mathrm{CH}_{3}$ & $1.33(\mathrm{~s})$ & & $4,3,12 b, 1$ & & 4,5 \\
\hline $1^{\prime}$ & $65.1, \mathrm{CH}$ & $5.17_{\text {ax }}(\mathrm{m})$ & $2^{\prime}$ & $3^{\prime}, 2^{\prime}, 10,9,8$ & $6^{\prime}, 3_{\mathrm{ax}}^{\prime}$ & $2^{\prime}, 3^{\prime}, 4^{\prime}, 1^{\prime}$ \\
\hline \multirow[t]{2}{*}{$2^{\prime}$} & $32.4, \mathrm{CH}_{2}$ & 1. $26_{\mathrm{ax}}(\mathrm{m})$ & $3^{\prime}, 1^{\prime}$ & $3^{\prime}, 1^{\prime}, 9,4^{\prime}$ & $4^{\prime}$ & $5^{\prime}, 1^{\prime}, 3^{\prime}$ \\
\hline & & $2.22_{\mathrm{eq}}(\mathrm{m})$ & & & $3_{\text {eq }}^{\prime}$ & \\
\hline \multirow[t]{2}{*}{$3^{\prime}$} & $23.2, \mathrm{CH}_{2}$ & $1.70_{\mathrm{ax}}(\mathrm{m})$ & $4^{\prime}, 2^{\prime}$ & $2^{\prime}, 4^{\prime}$ & $1^{\prime}, 6^{\prime}$ & $2^{\prime}, 6^{\prime}, 4^{\prime}, 5^{\prime}, 1^{\prime}$ \\
\hline & & $1.85_{\mathrm{eq}}(\mathrm{m})$ & & & $2_{\text {eq }}^{\prime}, 5^{\prime}$ & \\
\hline $4^{\prime}$ & $64.6, \mathrm{CH}$ & $2.36_{\mathrm{ax}}(\mathrm{m})$ & $5^{\prime}, 3^{\prime}$ & $6^{\prime}, 5^{\prime}$ & $2^{\prime}{ }_{\mathrm{ax}}$ & $2^{\prime}, 6^{\prime}, 3^{\prime}$ \\
\hline $5^{\prime}$ & $72.1, \mathrm{CH}$ & $4.58(\mathrm{~m})$ & $6^{\prime}, 4^{\prime}$ & $6^{\prime}, 3^{\prime}, 1^{\prime}, 4^{\prime}$ & $3_{\text {eq }}^{\prime}$ & $6^{\prime}, 3^{\prime}, 4^{\prime}$ \\
\hline $6^{\prime}$ & $12.3, \mathrm{CH}_{3}$ & $1.44_{\mathrm{ax}}(\mathrm{m})$ & $5^{\prime}$ & $4^{\prime}, 5^{\prime}$ & $1^{\prime}, 3_{\mathrm{ax}}^{\prime}$ & $3^{\prime}, 5^{\prime}$ \\
\hline $7^{\prime}$ & $43.5, \mathrm{CH}_{3}$ & $2.25(\mathrm{~s})$ & & $4^{\prime}$ & & \\
\hline $8^{\prime}$ & $43.5, \mathrm{CH}_{3}$ & $2.25(\mathrm{~s})$ & & $4^{\prime}$ & & \\
\hline $1^{\prime \prime}$ & $94.1, \mathrm{CH}$ & $5.75_{\mathrm{ax}}(\mathrm{s})$ & $2^{\prime \prime}$ & $3^{\prime \prime}, 5^{\prime \prime}, 4 \mathrm{a}$ & $3^{\prime \prime}{ }_{\mathrm{ax}}, 6^{\prime \prime}$ & $3^{\prime \prime}, 4^{\prime \prime}, 2^{\prime \prime}$ \\
\hline \multirow[t]{2}{*}{$2^{\prime \prime}$} & $31.1, \mathrm{CH}_{2}$ & $1.44_{\mathrm{ax}}(\mathrm{m})$ & $3^{\prime \prime}, 1^{\prime \prime}$ & $4^{\prime \prime}$ & $4^{\prime \prime}$ & \\
\hline & & $2.25_{\mathrm{eq}}(\mathrm{m})$ & & & $3^{\prime \prime}{ }_{\text {eq }}$ & \\
\hline \multirow[t]{2}{*}{$3^{\prime \prime}$} & $14.2, \mathrm{CH}_{2}$ & $1.14_{\mathrm{eq}}(\mathrm{m})$ & $4^{\prime \prime}, 2^{\prime \prime}$ & $5^{\prime \prime}, 1^{\prime \prime}, 4^{\prime \prime}$ & $1^{\prime \prime}, 6^{\prime \prime}$ & $7^{\prime \prime}, 4^{\prime \prime}, 2^{\prime \prime}, 5^{\prime \prime}, 1^{\prime \prime}$ \\
\hline & & $1.46_{\mathrm{ax}}(\mathrm{m})$ & & & $2^{\prime \prime}{ }_{\text {eq }}, 5^{\prime \prime}$ & \\
\hline $4^{\prime \prime}$ & $66.1, \mathrm{CH}$ & $1.93_{\mathrm{ax}}(\mathrm{m})$ & $5^{\prime \prime}, 3^{\prime \prime}$ & $6^{\prime \prime}, 5^{\prime \prime}, 3^{\prime \prime}$ & $2^{\prime \prime}$ ax & $6^{\prime \prime}, 3^{\prime \prime}, 2^{\prime \prime}, 5^{\prime \prime}, 1^{\prime \prime}$ \\
\hline $5^{\prime \prime}$ & $68.3, \mathrm{CH}$ & $3.65(\mathrm{~m})$ & $6^{\prime \prime}, 4^{\prime \prime}$ & $3^{\prime \prime}, 6^{\prime \prime}, 4^{\prime \prime}$ & $3^{\prime \prime}{ }_{\text {eq }}$ & $6^{\prime \prime}, 3^{\prime \prime}, 4^{\prime \prime}, 2^{\prime \prime}$ \\
\hline $6^{\prime \prime}$ & $19.1, \mathrm{CH}_{3}$ & $0.75_{\mathrm{ax}}(\mathrm{d}, 6.0)$ & $5^{\prime \prime}$ & $1^{\prime \prime}, 5^{\prime \prime}, 4^{\prime \prime}$ & $1^{\prime \prime}, 3^{\prime \prime}{ }_{\mathrm{ax}}$ & $3^{\prime \prime}, 4^{\prime \prime}, 2^{\prime \prime}, 5^{\prime \prime}$ \\
\hline $7^{\prime \prime}$ & $41.1, \mathrm{CH}_{3}$ & $2.05(\mathrm{~s})$ & & $4^{\prime \prime}$ & & \\
\hline $8^{\prime \prime}$ & $41.1, \mathrm{CH}_{3}$ & $2.05(\mathrm{~s})$ & & $4^{\prime \prime}$ & & \\
\hline
\end{tabular}

2.2. Cultivation of a Possible New Phylotype of Streptomyces sp.

The closest relative to Streptomyces sp. M7_15 searched through GenBank was Streptomyces sp. CNS-669-SD06 with a supporting 98\% sequence homology of a partial sequence of the 16S rRNA gene (Figure 4). This suggests the possibility that Streptomyces sp. M7_15 is a new phylotype [23] with the ability to produce new compounds, and in fact six new compounds related to frigocylinone were isolated from the EtOAc extract of the fermentation broth (Figure 2). Since frigocyclinone was previously isolated from a Streptomyces griseus species associated with soils of Antarctica, its partial 16S rRNA sequence was used to compare its genomic information to the 16S rRNA gene of Streptomyces sp. M7_15. Intriguingly, when the neighbor-joining tree was analyzed, these two strains were grouped into two separate clusters, showing a significantly distant relationship to one another (Figure 4). Therefore, it could be assumed that Streptomyces sp. M7_15 is a new actinomycete phylotype that has evolved similar biosynthetic genes to the Antarctic strain of $S$. griseus or that the presence of the pathways leading to angucyclinone production in one or both strains resulted from horizontal transfer and the two pathways 
have a common ancestor [24-26]. Distinguishing these two possibilities would require sequencing both pathways.

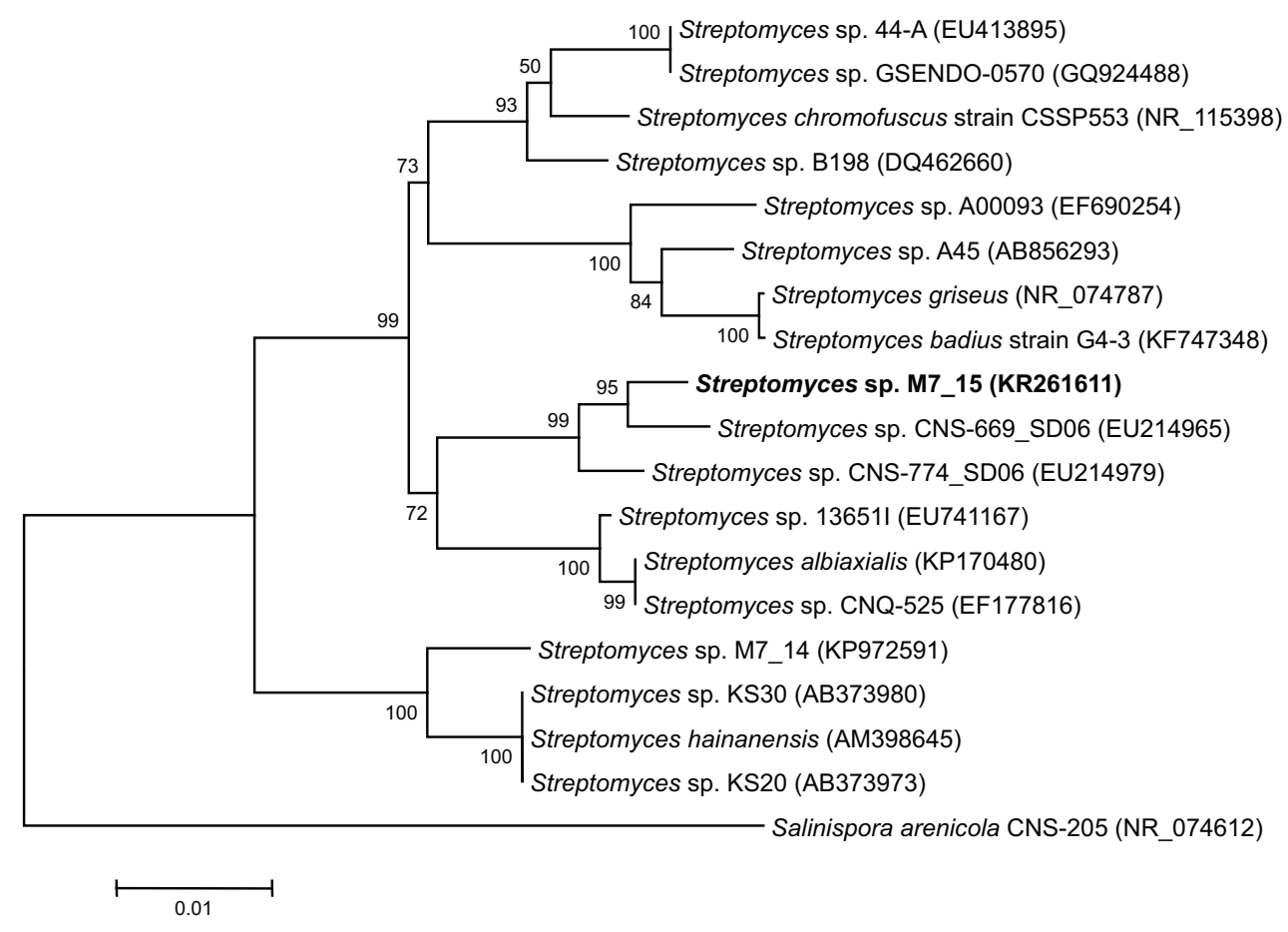

Figure 4. Neighbor-joining (NJ) tree of sponge and sediment associated actinomycetes based on partial sequence of 1400 base pairs of 16S rRNA genes. The tree was bootstrapped using 1000 replicates with the neighbor-joining algorithm. Scale bar $=0.01$ nucleotide substitutions per site. Accession numbers of each sequence are indicated in parenthesis.

\subsection{Biosynthetic Diversity of Angucyclinone Derivatives}

Aromatic polyketides biosynthesized by a type II PKS are divided into anthracyclines, angucyclines, and tetracyclines [10,11]. Derivatives of these can undergo further oxygenation, glycosylation and dehydration and show a wide range of biological activities [12,13,21,27]. The monacyclinones isolated in this study provide examples of many such post-PKS modifications of the angucyclinone moiety, and in some cases these modifications are extremely rare. It is possible to speculate that the early biosynthetic products of this organism are frigocyclinone (1) or monacyclinone $C$ (6) which undergo a series of further modifications. For example, either of these compounds could serve as precursors of 7 (and its hydrolysis product (8) following a Baeyer-Villiger oxygenation reaction. Such a reaction has been reported once in the generation of the angucyclinone derivative urdamycin $\mathrm{L}$, isolated from a mutated strain of the soil bacterium Streptomyces fradiae [22]. Urdamycin L, which possesses a seven-membered lactone moiety in ring A [21,22], is very similar in structure to monacyclinone D (7) and only lacks the $C$-linked deoxyamino sugar at C-9. It is proposed that lactone production is catalyzed by the protein oxygenase UrdM [22], and might be the pathway to hydroxylation at C-12b. Certainly the discovery of the monacyclinones 7-8 in a wild-type strain of a Streptomyces sp., tends to support this proposal. It is also likely that two separate glycosyltransferase enzymes operate in the $C$ - and $O$-glycosides found in monacyclinone $\mathrm{F}(9)$ as observed in other angucyclinone derivatives [11]. 
Another rare modification is the formation of two epoxide rings at positions 12a and 6 in monacyclinone F (9) and an angular oxygen at position C-4a. The placement of angular oxygens at C-12b and C-4a are widespread throughout many angucycline derivatives where the oxygens at these positions arise from acetate $(\mathrm{C}-4 \mathrm{a})$ and atmospheric oxygen $(\mathrm{C}-12 \mathrm{~b})$ via introduction by a monooxygenase [10]. The monooxygenases responsible for these modifications are characterized as flavin-dependent monooxygenases and a recent study on these tailoring enzymes found enormous functional flexibility and the ability to catalyze alternate reactions depending on the substrate, reaction conditions, and presence of other enzymes [28,29]. Flavin-dependent monooxygenases catalyze a variety of reactions, including hydroxylation, Baeyer-Villiger oxidation, and epoxidation. The structural diversity of the monacyclinones underscores the catalytic flexibility of these tailoring enzymes resulting in the immense structural diversity of the angucycline class of natural products.

\subsection{Biological Activity of Angucyclinone Derivatives}

Frigocyclinone (1), exhibited weak antibiotic activity against Bacillus subtilis [17]. In addition, frigocyclinone showed an inhibition zone of $1 \mathrm{~mm}$ at a concentration of $1 \mathrm{mg} / \mathrm{mL}$ against Mycobacterium smegmatis (Table S9). No inhibition was observed against gram negative or fungal organisms at the concentrations tested. This compound also showed cytotoxicity against human rhabdomyosarcoma SJCRH30 cells with an $\mathrm{EC}_{50}$ value of $5.2 \mu \mathrm{M}$ at $48 \mathrm{~h}$ post treatment (Table 3; Figures S20 and S21).

Table 3. EC 50 of frigocyclinone, dimethyldehydrorabelomycin, and all new monacyclinone derivatives after $24 \mathrm{~h}$ and $48 \mathrm{~h}$ intervals against rhabdomyosarcoma cancer cells. EC50s are reported as $>10 \mu \mathrm{M}$ if the highest dose of the compound failed to kill $50 \%$ of the cells in that treatment.

\begin{tabular}{ccc}
\hline Compound & $\mathbf{E C}_{\mathbf{5 0}} \mathbf{2 4} \mathbf{h}(\boldsymbol{\mu M})$ & $\mathbf{E C}_{\mathbf{5 0}} \mathbf{4 8} \mathbf{h}(\boldsymbol{\mu M})$ \\
\hline Frigocyclinone (1) & $>10$ & 5.2 \\
Dimethyldehydrorabelomycin (3) & $>10$ & $>10$ \\
4 & $>10$ & $>10$ \\
5 & $>10$ & $>10$ \\
6 & $1.1 \times 10^{2}$ & $1.6 \times 10^{2}$ \\
7 & $>10$ & $>10$ \\
8 & $>10$ & $2.7 \times 10^{2}$ \\
9 & $6.1 \times 10^{-1}$ & $7.3 \times 10^{-1}$ \\
\hline
\end{tabular}

Modifications to the angucyclinone moiety resulted in a wide variety of bioactivity profiles against the human rhabdomyosarcoma SJCRH30 cells for the monacyclinone derivatives (Figures S20 and S21; Table 3). Of all the derivatives tested, compound 9, which has two aminodeoxysugars attached to the angucyclinone moiety, exhibited the strongest cytotoxicity against bacteria and human rhabdomyosarcoma SJCRH30 cells. This metabolite registered $\mathrm{EC}_{50}$ values of $610 \mathrm{nM}$ and $730 \mathrm{nM}$ $24 \mathrm{~h}$ and $48 \mathrm{~h}$ post treatment, respectively (Table 3 ). In contrast to compound $\mathbf{9}$, compounds $\mathbf{4 - 8}$ with an aromatic ring and only one aminodeoxysugar unit showed weak to no bioactivity against gram-positive bacteria and human rhabdomyosarcoma SJCRH30 cells (Table 3; Table S9). Moreover compound 3, that lacks both aminodeoxysugars, shows weak bioactivity in all the bioassays conducted (Tables 3 and S9). 
As indicated by their structures, these bioactivity results suggest that the aminodeoxysugar subunit, the epoxide groups, and the ketone moiety could all be important for biological activity.

\section{Experimental Section}

\subsection{General Experimental}

All media components and chemicals were purchased from Fisher Scientific (Waltham, MA, USA). Optical rotation data were recorded on a Rudolph Research Analytical Autopol III automatic polarimeter (Rudolf Research, Fairfield, NJ, USA). UV spectra were recorded on a Beckman DU 640 spectrophotometer (Beckman Instruments, Fullerton, CA, USA). ${ }^{1} \mathrm{H}$ NMR, COSY, HSQC, and HMBC spectra were recorded in methanol- $d_{4}$ or pyridine- $d_{5}$ using a $500 \mathrm{MHz}$ Bruker NMR Avance spectrometer (Bruker, Billerica, MA, USA). Chromatography for LC/MS was performed using a Hewlett-Packard 1100 HPLC system equipped with a diode array detector (Hewlett-Packard, Avondale, CA, USA) using a Waters XTerra MS C18 column $(2.1 \times 30 \mathrm{~mm})$ (Waters, Milford, MA, USA) and a gradient mobile phase of $\mathrm{MeCN} / \mathrm{H}_{2} \mathrm{O}$ each containing $0.1 \%$ acetic acid. A Waters Micromass ZQ detector (Waters, Milford, MA, USA) equipped with an electrospray ionization source was used to acquire mass spectrometric data (capillary voltage $3.5 \mathrm{kV}$; cone voltages $30 \mathrm{~V} / 50 \mathrm{~V}$; source temperature $100{ }^{\circ} \mathrm{C}$; desolvation temperature $400{ }^{\circ} \mathrm{C}$; cone gas flow $60 \mathrm{~L} / \mathrm{h}$; desolvation gas flow $450 \mathrm{~L} / \mathrm{h}$ ). All samples were run in both positive and negative ion mode with a mass range of 100-1400 Da and a scan time of $0.5 \mathrm{~s}$ The LC/MS data were analyzed using MassLynx 4.1 (Waters, Milford, MA, USA). High-resolution mass measurements were outsourced to the University of Illinois SCS Mass Spectrometry Lab (Urbana, IL, USA). HPLC was conducted on a Waters 1525 HPLC (Waters, Milford, MA, USA) coupled with a Waters 2487 dual $\lambda$ absorbance detector (Waters, Milford, MA, USA). The UV wavelengths used for separations were 214 and $250 \mathrm{~nm}$. The flow rate of the mobile phase was $4 \mathrm{~mL} / \mathrm{min}$ for $10 \mathrm{~mm}$ columns and $0.8 \mathrm{~mL} / \mathrm{min}$ for $4.6 \mathrm{~mm}$ columns.

\subsection{Isolation of Streptomyces sp. M7_15}

Strain Streptomyces sp. M7_15 was isolated from the Caribbean marine sponge Scopalina ruetzleri. The sponge S. ruetzleri was collected by SCUBA at a depth of $20 \mathrm{~m}$ on Las Carmelitas dive site located in Mona Island, Puerto Rico (18 $6^{\prime} 25.72^{\prime \prime}$ N, 67 56 $\left.11.35^{\prime \prime} \mathrm{W}\right)$. A volume of $1 \mathrm{~mL}$ of sponge tissue was scraped from the coral bottom with a sterile razor blade and transferred to a $50-\mathrm{mL}$ sterile tube with sterilized tweezers. Sterile mortars and pestles were used to homogenize the sponge before dilution. The sponge homogenate was then treated with heat $\left(55^{\circ} \mathrm{C}\right.$ for $\left.60 \mathrm{~min}\right)$ and agitation (vortexed for $1 \mathrm{~min}$ ) in order to select for actinomycetes. Media M6 (1 L 75\% ocean seawater, $500 \mathrm{mg}$ mannitol, $100 \mathrm{mg}$ peptone and $18 \mathrm{~g}$ agar [30]) was used to isolate Streptomyces sp. M7_15. M6 media was supplemented with $50 \mu \mathrm{g} / \mathrm{mL}$ of the fungicide cyclohexamide and $20 \mu \mathrm{g} / \mathrm{mL}$ of the antibiotic novobiocin to facilitate the isolation of actinobacteria and deter the growth of sponge associated fungi and gram-negative bacteria on the plates [30,31]. Aliquots of $100 \mu \mathrm{L}$ were transferred from the S. ruetzleri homogenate dilution to the M6 media. After 8 weeks of incubation of the sponge homogenate from Scopalina ruetzleri, the actinomycete strain Streptomyces sp. M7_15 appeared as a brown circular colony that 
produced white spores and a dark purple diffusible pigment. The strain is kept in culture on agar slants as well as cryopreserved.

\subsection{DNA Extraction, Sequencing and Phylogenetic Analysis}

DNA was extracted from a $20 \mathrm{mg}$ pellet of cells from a pure isolate using the Gentra Puregene kit (Qiagen, Valencia, CA, USA). The 16S rRNA gene was amplified using polymerase chain reaction (PCR) with universal eubacterial primers $27 \mathrm{~F}$ and 1492R [32,33]. The PCR mix consisted of $39.3 \mu \mathrm{L}$ of nuclease free water, $0.2 \mu \mathrm{L}$ of Platinum Taq DNA Polymerase High Fidelity (Invitrogen, Carlsbad, CA, USA), $1 \mu \mathrm{L}(40 \mathrm{ng} / \mu \mathrm{L})$ of each primer, and $1 \mu \mathrm{L}(100 \mathrm{ng} / \mu \mathrm{L})$ of DNA template. The PCR program was set to an initial denaturation at $95{ }^{\circ} \mathrm{C}$ for $2.5 \mathrm{~min}$, followed by 35 cycles of $95{ }^{\circ} \mathrm{C}$ for $30 \mathrm{~s}, 45^{\circ} \mathrm{C}$ for $30 \mathrm{~s}, 72{ }^{\circ} \mathrm{C}$ for $1 \mathrm{~min}$, and a final extension during the last cycle of $72{ }^{\circ} \mathrm{C}$ for $10 \mathrm{~min}$. Results of PCR reactions were observed on $1 \%$ agarose gels. Sequencing reactions were conducted with $685 \mathrm{R}$ primer and Big Dye terminator (Applied Biosystems, Foster City, CA, USA). The reaction products were analyzed with a 3130XL Genetic Analyzer (Applied Biosystems, Foster City, CA, USA). Sequences were assembled and edited using Sequencher 5.2.4 (Gene Codes, Ann Arbor, MI, USA). Double coverage reads allowed for accurate editing of sequences. The complete consensus sequence was exported into a single Fasta file from Sequencher and uploaded with MEGA 5 (Gene Codes, Ann Arbor, MI, USA) [34]. Sequences were then aligned using the ClustalW function with default parameters (ClustalW, University College Dublin, Dublin, Ireland). The closest relative to our sequence was searched using the BLAST function from GenBank. These sequences were used as reference sequences for alignment and tree generating purposes. MEGA 5 was used to construct a phylogenetic tree of the 16S rRNA gene using a neighbor-joining (NJ) analysis. The NJ analysis was performed using a maximum composite likelihood model of nucleotide substitution and data was re-sampled using 1000 bootstrap replicates.

\subsection{Chemical Analysis of Actinomycetes}

Streptomyces sp. M7_15 was fermented in large scale in P3C media (10 g starch, 4 g yeast, 2 g peptone, $1 \mathrm{~g} \mathrm{CaCO}_{3}, 40 \mathrm{mg} \mathrm{Fe}_{2} \mathrm{SO}_{4}, 100 \mathrm{mg} \mathrm{KBr}$, in $1 \mathrm{~L}$ of $75 \%$ seawater) over a period of 3 months. Batches (1.6 L total volume) of Streptomyces sp. M7_15 were cultured at $28^{\circ} \mathrm{C}$ on a rotary shaker (IKA, Wilmington, NC, USA) in $500 \mathrm{~mL}$ flasks containing $100 \mathrm{~mL}$ of media each during a period of 9 days on a rotary shaker $(200 \mathrm{rpm})$. Cells and fermented broth were harvested by vacuum filtration using glass fiber filters (GF/C) (Whatman, Maidstone, UK). Media was extracted by liquid-liquid partitioning using ethyl acetate $(\mathrm{EtOAc})$ and butanol $(\mathrm{BuOH})(2: 1)$. The cells retained on the glass fiber filter were extracted with $80 \%$ aq. $\mathrm{MeOH}$. Extracts were monitored by LC/MS and tested for antimicrobial activities against gram positive (Bacillus subtilis and Mycobacterium smegmatis), gram negative (Escherechia coli) and fungal (Aspergillus niger and Candida kefyr) organisms.

\subsection{Purification of Monacyclinones from Streptomyces sp. M7_15}

LC/MS analysis and antibiotic assays of the crude EtOAc extract $(986 \mathrm{mg}$ ) showed potent bioactivity and displayed characteristic UV spectral data (190 nm and $234 \mathrm{~nm}$ ). Subsequently, this extract was 
suspended in $1.5 \mathrm{~mL}$ of $20 \%$ aqueous $\mathrm{MeOH}$ and was fractionated using a reversed-phase $\mathrm{C}_{18} \mathrm{Sep}$-pak (10 g) column (Waters Associates, Milford, MA, USA) with a step gradient of $\mathrm{MeOH} / \mathrm{H}_{2} \mathrm{O}$ elution. Seven fractions were collected starting at $20 \% \mathrm{MeOH}$ with increments of $20 \% \mathrm{MeOH}$ followed by dichloromethane $\left(\mathrm{CH}_{2} \mathrm{Cl}_{2}\right)$ and $0.1 \%$ TFA in $\mathrm{MeOH}$ washes. LC-MS and antibiotic activity of the fractions indicated that the antimicrobial compounds were distributed in the $80 \%-100 \% \mathrm{MeOH}$ fractions with the highest concentration in $80 \% \mathrm{MeOH}$ (306 mg). Subsequent fractionation was performed using a reversed-phase $\mathrm{C}_{18}$ Baker Bond (6 g) column (Baker-bond, Philipsburg, NJ, USA) and a stepwise elution gradient of $\mathrm{MeOH} / \mathrm{H}_{2} \mathrm{O}$ starting with $60 \% \mathrm{MeOH}$. Fractions were collected according to the color of the bands as they eluted from the column. A total of 14 fractions were collected and three fractions (70 mgs each) following $80 \% \mathrm{MeOH}$ elution showed the most potent activity. These fractions were further purified by HPLC using a semiprep $\mathrm{C}_{18}$ column (Sun Fire, Petaluma, CA, USA; $10 \times 250 \mathrm{~mm}$, $5 \mu \mathrm{m})$ with a gradient mobile phase $(20 \%-70 \% \mathrm{MeOH}$ over $28 \mathrm{~min})$. Active fractions obtained from this step were further fractionated using an analytical $\mathrm{C}_{18}$ column (Sun Fire, Petaluma, CA, USA; $4.6 \times 150 \mathrm{~mm}$, $3.5 \mu \mathrm{m})$ and a gradient mobile phase $30 \%-45 \%$ acetonitrile $(\mathrm{ACN})$. This final fractionation process yielded 1-10 mg of each of 8 active compounds that were eventually identified as frigocyclinone (1), dimethyldehydrorabelomycin (3) and monacyclinones A-F (4-9).

Frigocyclinone (1): Yellow powder; ${ }^{1} \mathrm{H}$ NMR (500 MHz) and ${ }^{13} \mathrm{C}$ NMR (125 MHz,) see Table S1; HRESIMS (+) $m / z 464.2061$ (calcd for $\mathrm{C}_{21} \mathrm{H}_{17} \mathrm{O}_{5} 464.2073 \Delta=-2.6 \mathrm{ppm}$ ).

Dimethyldehydrorabelomycin (3): Red powder, $[\alpha]_{\mathrm{D}}^{25} 63^{\circ}(c 0.9, \mathrm{DMSO}) ; \mathrm{UV}$ (Pyridine) $\lambda_{\max }(\log \varepsilon)$ 318 (3.6), 290 (3.44), 415 (3.21); ${ }^{1} \mathrm{H}$ NMR (500 MHz) and ${ }^{13} \mathrm{C}$ NMR (125 MHz) see Table S2; HRESIMS (+) $m / z 349.1071$ (calcd for $\mathrm{C}_{21} \mathrm{H}_{17} \mathrm{O}_{5} 349.1076 \Delta=-1.4 \mathrm{ppm}$ ).

Monacyclinone A (4): yellow powder, $[\alpha]_{\mathrm{D}}^{25} 50^{\circ}$ (c 1.8, DMSO); UV (Pyridine) $\lambda \max (\log \varepsilon) 315$ (3.44), 280 (3.12), 422 (3.0); ${ }^{1} \mathrm{H}$ NMR (500 MHz) and ${ }^{13} \mathrm{C}$ NMR (125 MHz) see Table S3; HRESIMS $(+) \mathrm{m} / \mathrm{z}$ 446.1974 (calc for $\mathrm{C}_{27} \mathrm{H}_{28} \mathrm{NO}_{5} 446.1967 \Delta=1.6 \mathrm{ppm}$ ).

Monacyclinone B (5): orange powder, $[\alpha]_{\mathrm{D}}^{25} 43^{\circ}$ (c 1.0, DMSO); UV (Pyridine) $\lambda \max (\log \varepsilon) 328$ (3.19), 299 (4.9), 445 (3.13); ${ }^{1} \mathrm{H}$ NMR (500 MHz) and ${ }^{13} \mathrm{C}$ NMR (125 MHz) see Table S4; HRESIMS (+) $\mathrm{m} / \mathrm{z}$ 462.1917 (calc for $\mathrm{C}_{27} \mathrm{H}_{28} \mathrm{NO}_{6} 462.1917 \Delta=0.0 \mathrm{ppm}$ ).

Monacyclinone C (6): yellow powder, $[\alpha]_{\mathrm{D}}^{25} 15^{\circ}(c 1.5$, DMSO); UV (Pyridine) $\lambda \max (\log \varepsilon) 280$ (3.21), 429 (2.98), 301 (2.91); ${ }^{1} \mathrm{H}$ NMR (500 MHz) and ${ }^{13} \mathrm{C}$ NMR (125 MHz) see Table S5; HRESIMS (+) $\mathrm{m} / \mathrm{z}$ 480.2027 (calc for $\mathrm{C}_{27} \mathrm{H}_{30} \mathrm{NO}_{7} 480.2022 \Delta=1.0 \mathrm{ppm}$ ).

Monacyclinone D (7): yellow powder, $[\alpha]_{\mathrm{D}}^{25} 9^{\circ}\left(c\right.$ 1.5, DMSO); UV (Pyridine) $\lambda_{\max }(\log \varepsilon) 440$ (3.44), 285 (3.36), 404 (3.28); ${ }^{1} \mathrm{H}$ NMR (500 MHz) and ${ }^{13} \mathrm{C}$ NMR (125 MHz) see Table S6; HRESIMS (+) $\mathrm{m} / \mathrm{z}$ 480.2022 (calc for $\mathrm{C}_{27} \mathrm{H}_{30} \mathrm{NO}_{7} 480.2022 \Delta=0.0 \mathrm{ppm}$ ).

Monacyclinone E (8): yellow powder, $[\alpha]_{\mathrm{D}}^{25} 12^{\circ}$ (c 1.5, DMSO); UV (Pyridine) $\lambda_{\max }(\log \varepsilon) 440$ (3.44), 285 (3.36), 404 (3.28); ${ }^{1} \mathrm{H}$ NMR (500 MHz) and ${ }^{13} \mathrm{C}$ NMR (125 MHz) see Table S7; HRESIMS (+) $\mathrm{m} / \mathrm{z}$ 498.2124 (calc for $\mathrm{C}_{27} \mathrm{H}_{32} \mathrm{NO}_{8} 498.2128 \Delta=-0.8 \mathrm{ppm}$ ).

Monacyclinone F (9): purple oil, $[\alpha]_{\mathrm{D}}^{25} 80^{\circ}$ (c 3.5, DMSO); UV (Pyridine) $\lambda_{\max }(\log \varepsilon) 367$ (3.18), 281 (314), 298 (3.00); ${ }^{1} \mathrm{H}$ NMR (500 MHz) and ${ }^{13} \mathrm{C}$ NMR (125 MHz) see Table S8; HRESIMS (+) $\mathrm{m} / \mathrm{z}$ 655.3253 (calc for $\mathrm{C}_{35} \mathrm{H}_{47} \mathrm{~N}_{2} \mathrm{O}_{10} 655.3231 \Delta=3.44 \mathrm{ppm}$ ). 


\subsection{Image Based Cytotoxicity Assay Using SJCRH30 (Rhabdomyosarcoma) Cells}

Cytotoxicity was assessed using a live cell imaged based assay that utilizes the fluorescent nuclear stain Hoechst 33342 (H-dye) (Sigma, St Louis, MO, USA) and the fluorescent microtubule stain Tubulin Tracker 488 (Life Technologies, Gaithersburg, MD, USA) [35]. For this assay, the most sensitive cell line for marine toxins was found to be the SJCRH30 cells. In addition to being very sensitive to marine toxins, these cells are large and spread out which allows for counting efficiency for live cell imaging and allowed for easier measurement and visualization of morphological changes associated with toxin. Comparison of the half maximal effective concentration $\left(\mathrm{EC}_{50}\right)$ values for the traditional XTT cytotoxicity assay and the in vitro microscopy assay using the human cell line model (SJCHR30) showed no significant difference between the assays [35], therefore the in vitro cytotoxicity assay was used to determine the $\mathrm{EC}_{50}$ values for the marine derived products in this manuscript.

Cytotoxicity was measured using fluorescence staining of cell nucleii. Initially, SJCRH30 cells were seeded at a density of 5000 cells/well in BD biocoat poly-D-lysine-coated 96-well plates (Becton Dickinson, Franklin Lakes, NJ, USA) and incubated at $37{ }^{\circ} \mathrm{C}$ overnight. Cells were then treated with $10 \times$ solutions of compounds added directly to the growth medium (RPMI 1640 supplemented with 10\% FBS) and incubated at $37^{\circ} \mathrm{C}$ for the designated time period. Cell nucleii were stained with a $0.1 \mu \mathrm{g} / \mathrm{mL}$ final concentration of Hoechst 33342 (Invitrogen, Grand Island, NY, USA) at the same time as the compound treatment. $10 \mu \mathrm{L}$ of $10 \times$ Hoechst dye in Phosphate Buffered Saline was added directly to the growth medium in the wells, and the plate was incubated at $37{ }^{\circ} \mathrm{C}$ for the remaining time. Cells had to be stained in two separate steps because Hoechst 33,342 is not compatible with the Hanks Buffered Saline Solution (HBSS) that is required for the tubulin staining protocol.

To stain microtubules with Tubulin Tracker 488 (TT488), a $500 \mu \mathrm{M}$ intermediate stock was first prepared by combining $1 \mathrm{mM}$ TT488 (Invitrogen, Camarillo, CA, USA) with an equal volume of 20\% Pluronic F-127 in DMSO (Invitrogen, Camarillo, CA, USA). Then a $200 \mathrm{nM}$ TT488 staining solution was prepared from the intermediate stock in HBSS. The growth medium containing the Hoechst dye was removed from the wells, and the cells were rinsed once with warm HBSS (100 $\mu \mathrm{L}$ per well). The HBSS rinse was replaced with warmed $200 \mathrm{nM}$ TT488 staining solution (100 $\mu \mathrm{L}$ per well). The plate was then returned to the $37{ }^{\circ} \mathrm{C}$ incubator for 20 min before imaging on an Image Xpress Micro system (Molecular Devices, Sunnyvale, CA, USA), equipped with an environmental control chamber warmed to $37^{\circ} \mathrm{C}$. The intensity of the fluorescence of the Hoechst dye stain was measured on the DAPI channel and that of the TT488 was measured on the FITC channel of the Image Xpress Micro (Molecular Devices, Sunnyvale, CA, USA) using the MetaXpress Image Acquisition and Analysis v2.0.1.44 software (Molecular Devices, Sunnyvale, CA, USA). The percentage of DAPI positively-stained cells as compared to control treatments (percentage of maximum cell survival) averaged within 4 snapshots of each well were calculated with SAS v9.1.3 software (SAS Institute Inc., Cary, NC, USA) and analyzed with non-linear regression curve-fit analysis by GraphPad Prism v4.03 (Graphpad, San Diego, CA, USA) to yield $\mathrm{EC}_{50}$ values. In addition, pictures of cells from the cytotoxicity experiments stained with Hoechst dye and Tubulin Tracker were visualized using the MetaXpress Image Acquisition and Analysis v2.0.1.44 software (Molecular Devices, Sunnyvale, CA, USA). 
EC50 values were determined using an ANOVA SAS v9.1.3 software (SAS Institute Inc., Cary, NC, USA). In all experiments, results are presented as the mean \pm SD and were considered statistically significant if a $p$-value was less than 0.05 .

\section{Conclusions}

This study describes six new angucyclinone derivatives which, in addition to frigocyclinone, add to the list of angucyclinones with a $C$-linked aminodeoxysugar. Several novel features include the second appearance of a lactone ring as part of the angucyclinone moiety (compound 7) and the addition of a second aminodeoxysugar with two epoxide rings (compound 9). These compounds are an example of the remarkable biosynthetic ability of marine sponge-associated Streptomyces sp. to produce bioactive secondary metabolites. Despite the weak biological activities of monacyclinones A-E (4-8), monacyclinone F (9) with an additional aminodeoxysugar moiety showed potent bioactivity against rhabdomyosarcoma SJCRH30 cells. These bioactivity profiles should encourage further bioassays of angucyclinone derivatives against other cancer cell lines.

\section{Acknowledgments}

Funding for this study was supported by the Carl B. Brown Trust Fund (JLCW) and the state of North Carolina that provided funding to MARBIONC, a marine biotechnology initiative at UNCW. Additional support was provided by the UNCW Brauer Fellowship that funded the sponge collection trip to Mona, Puerto Rico. J.V. is indebted to Alex Méndez who made the travel arrangements and was responsible for all of the logistics involved in the trip to Mona Island. J.V. acknowledges support from the NOAA Living Marine Resources Cooperative Science Center (NA11SEC4810002).

\section{Author Contributions}

Jeffrey L.C. Wright and Jan Vicente designed the study. Jan Vicente collected the organisms. Jan Vicente, Ryan M. Van Wagoner, Allison K. Stewart, and Jeffrey L.C. Wright contributed to the structure elucidation of the compounds. E.E. and A.J.B. conducted the cytotoxicity assays. Jan Vicente, Allison K. Stewart and Jeffrey L.C. Wright prepared the manuscript.

\section{Conflicts of Interest}

The authors declare no conflict of interest.

\section{Abbreviations}

NMR: Nuclear Magnetic Resonance; COSY: Correlation Spectroscopy; HMBC: Heteronuclear Multiple-Bond Connectivity; ROESY: Rotating frame Nuclear Overhauser Spectroscopy; HSQC: Heteronuclear Single Quantum Coherence; TOCSY: Total Correlation Spectroscopy; HPLC: High Performance Liquid Chromatography; LC/MS: Liquid Chromatography/Mass Spectrometry. 


\section{References}

1. Abdelmohsen, U.R.; Bayer, K.; Hentschel, U. Diversity, abundance and natural products of marine sponge-associated actinomycetes. Nat. Prod. Rep. 2014, 31, 381-399.

2. Dharmaraj, S.; Sumantha, A. Bioactive potential of Streptomyces associated with marine sponges. World J. Microb. Biotech. 2009, 25, 1971-1979.

3. Li, K.; Li, Q.L.; Ji, N.Y.; Liu, B.; Zhang, W.; Cao, X.P. Deoxyuridines from the marine sponge associated actinomycete Streptomyces microflavus. Mar. Drugs 2011, 9, 690-695.

4. Nair, A.G.; Selvakumar, D.; Dhevendaran, K. Occurrence of sponges associated Streptomyces and its antimicrobial activity. World J. Fish Mar. Sci. 2011, 3, 151-158.

5. Schneemann, I.; Kajahn, I.; Ohlendorf, B.; Zinecker, H.; Erhard, A.; Nagel, K.; Wiese, J.; Imhoff, J.F. Mayamycin, a cytotoxic polyketide from a Streptomyces strain isolated from the marine sponge Halichondria panicea. J. Nat. Prod. 2010, 73, 1309-1312.

6. Khan, S.T.; Komaki, H.; Motohashi, K.; Kozone, I.; Mukai, A.; Takagi, M.; Shin-ya, K. Streptomyces associated with a marine sponge Haliclona sp.; Biosynthetic genes for secondary metabolites and products. Environ. Microbiol. 2011, 13, 391-403.

7. Olano, C.; Méndez, C.; Salas, J.A. Antitumor compounds from actinomycetes: From gene clusters to new derivatives by combinatorial biosynthesis. Nat. Prod. Rep. 2009, 26, 628-660.

8. Abdelfattah, M.S.; Kharel, M.K.; Hitron, J.A.; Baig, I.; Rohr, J. Moromycins A and B, isolation and structure elucidation of $C$-glycosylangucycline-type antibiotics from Streptomyces sp. Ky002. J. Nat. Prod. 2008, 71, 1569-1573.

9. Fotso, S.; Mahmud, T.; Zabriskie, T.M.; Santosa, D.A.; Proteau, P.J. Angucyclinones from an Indonesian Streptomyces sp. J. Nat. Prod. 2007, 71, 61-65.

10. Rohr, J.; Thiericke, R. Angucycline group antibiotics. Nat. Prod. Rep. 1992, 9, 103-137.

11. Kharel, K.K.; Pahari, P.; Shepher, M.D.; Tibrewal, N.; Nybo, S.E.; Shaaban, K.A.; Rohr, R. Angucyclines: Biosynthesis, mode-of-action, new natural products, and synthesis. Nat. Prod. Rep. 2012, 29, 264-325.

12. Xie, Z.; Liu, B.; Wang, H.; Yang, S.; Zhang, H.; Wang, Y.; Ji, N.; Qin, S.; Laatsch, H. Kiamycin, a unique cytotoxic angucyclinone derivative from a marine Streptomyces sp. Mar. Drugs 2012, 10, 551-558.

13. Bringmann, G.; Lang, G.; Maksimenka, K.; Hamm, A.; Gulder, T.A.M.; Dieter, A.; Bull, A.T.; Stach, J.E.M.; Kocher, N.; Müller, W.E.G. Gephyromycin, the first bridged angucyclinone, from Streptomyces griseus strain NTK 14. Phytochemistry 2005, 66, 1366-1373.

14. Ren, X.; Lu, X.; Ke, A.; Zheng, Z.; Lin, J.; Hao, W.; Zhu, J.; Fan, Y.; Ding, Y.; Jiang, Q. Three novel members of angucycline group from Streptomyces sp. N05wa963. J. Antibiot. 2011, 64, 339-343.

15. Wiedenmayer, F. Shallow-water sponges of the western Bahamas. Experientia. Suppl. 1977, 28, 1-43.

16. Vicente, J.; Stewart, A.; Song, B.; Hill, R.T.; Wright, J.L.C. Biodiversity of actinomycetes associated with Caribbean sponges and their potential for natural product discovery. Mar. Biotechnol. 2014, $15,413-424$. 
17. Bruntner, C.; Binder, T.; Pathom-aree, W.; Goodfellow, M.; Bull, A.T.; Potterat, O.; Puder, C.; Hörer, S.; Schmid, A.; Bolek, W. Frigocyclinone, a novel angucyclinone antibiotic produced by a Streptomyces griseus strain from Antarctica. J. Antibiot. 2005, 58, 346-349.

18. Kuntsmann, M.P.; Mitscher, L.A. The structural characterization of tetrangomycin and tetrangulol. J. Org. Chem. 1966, 31, 2920-2925.

19. Seaton, P.; Gould, S.J. Kinamycin biosynthesis. Derivation by excision of an acetate unit from a single-chain decaketide intermediate. J. Am. Chem. Soc. 1987, 109, 5282-5284.

20. Tibrewal, N.; Pahari, P.; Wang, G.; Kharel, M.K.; Morris, C.; Downey, T.; Hou, Y.; Bugni, T.S.; Rohr, J. Baeyer-Villiger $C-C$ bond cleavage reaction in gilvocarcin and jadomycin biosynthesis. J. Am. Chem. Soc. 2012, 134, 18181-18184.

21. Rix, U.; Fischer, C.; Remsing, L.L.; Rohr, J. Modification of post-PKS tailoring steps through combinatorial biosynthesis. Nat. Prod. Rep. 2002, 19, 542-580.

22. Rix, U.; Remsing, L.L.; Hoffmeister, D.; Bechthold, A.; Rohr, J. Urdamycin L: A novel metabolic shunt product that provides evidence for the role of the $u r d M$ gene in the urdamycin A biosynthetic pathway of Streptomyces fradiae tü 2717. Chem. Bio. Chem. 2003, 4, 109-111.

23. Gontang, E.A.; Fenical, W.; Jensen, P.R. Phylogenetic diversity of gram-positive bacteria cultured from marine sediments. Appl. Environ. Microbiol. 2007, 73, 3272-3282.

24. Dröge, M.; Pühler, A.; Selbitschka, W. Horizontal gene transfer among bacteria in terrestrial and aquatic habitats as assessed by microcosm and field studies. Biol. Fertil. Soil. 1999, 29, 221-245.

25. Thomas, C.M.; Nielsen, K.M. Mechanisms of, and barriers to, horizontal gene transfer between bacteria. Nat. Rev. Microbiol. 2005, 3, 711-721.

26. Tolba, S.; Wellington, E.M. Horizontal gene transfer within Streptomycetes. Microbiol. Aust. 2004, $25,34-35$.

27. Olano, C.; Méndez, C.; Salas, J.A. Antitumor compounds from marine actinomycetes. Mar. Drugs 2009, 7, 210-248.

28. Thibodeaux, C.J.; Chang, W.; Liu, H. Enzymatic chemistry of cyclopropane, epoxide, and airidine biosynthesis. Chem. Rev. 2012, 112, 1681-1709.

29. Patrikainen, P.; Kallio, P.; Fan, K.; Klika, K.D.; Shaaban, K.A.; Mantsala, P.; Rohr, J.; Yang, K.; Niemi, J.; Metsa-Ketela, M. Tailoring enzymes involved in the biosynthesis of angucyclines contain latent context-dependent catalytic activities. Chem. Biol. 2012, 19, 647-655.

30. Jensen, P.R.; Gontang, E.; Mafnas, C.; Mincer, T.J.; Fenical, W. Culturable marine actinomycete diversity from tropical Pacific Ocean sediments. Environ. Microbiol. 2005, 7, 1039-1048.

31. Shockman, G.D.; Lampen, J.O. Inhibition by antibiotics of the growth of bacterial and yeast protoplasts. J. Bacteriol. 1962, 84, 508-512.

32. Farris, M.; Olson, J. Detection of actinobacteria cultivated from environmental samples reveals bias in universal primers. Lett. Appl. Microbiol. 2007, 45, 376-381.

33. Reysenbach, A.L.; Giver, L.J.; Wickham, G.S.; Pace, N.R. Differential amplification of rRNA genes by polymerase chain reaction. Appl. Environ. Microbiol. 1992, 58, 3417-3418.

34. Tamura, K.; Peterson, D.; Peterson, N.; Stecher, G.; Nei, M.; Kumar, S. MEGA5: Molecular evolutionary genetics analysis using maximum likelihood, evolutionary distance, and maximum parsimony methods. Mol. Biol. Evol. 2011, 28, 2731-2739. 
35. McCall, J.R.; Elliott, E.A.; Bourdelais, A.J. A new cytotoxicity assay for brevetoxins using fluorescence microscopy. Mar. Drugs 2014, 12, 4868-4882.

(C) 2015 by the authors; licensee MDPI, Basel, Switzerland. This article is an open access article distributed under the terms and conditions of the Creative Commons Attribution license (http://creativecommons.org/licenses/by/4.0/). 